\title{
Bioactive compounds identification and physicochemical characterization from Nopalea cochenillifera (L.) Salm-Dyck cladodes flour
}

\author{
Identificación de compuestos bioactivos y características fisicoquímicas de la harina de cladodios \\ de Nopalea cochenillifera (L.) Salm-Dyck
}

\begin{abstract}
Héctor Enrique Fabela-Illescas ${ }^{1}$, Marisol Patricia Castro-Mendoza', Efigenia Montalvo-González² ${ }^{2}$ Luis Miguel AnayaEsparza ${ }^{3}$, Apolonio Vargas-Torres ${ }^{1}$, Gabriel Betanzos-Cabrera ${ }^{4}$, Juan Pablo Hernández-Uribe ${ }^{1 *}$

Universidad Autónoma del Estado de Hidalgo, Instituto de Ciencias Agropecuarias, Av. Universidad Km 1, Rancho Universitario, C.P. 43600, Tulancingo de Bravo, Hidalgo, México.

2 Laboratorio Integral de Investigación en Alimentos, División de Estudios de Posgrado, TecNM/Instituto Tecnológico de Tepic. Av. Instituto Tecnológico No 2595. 63175, Col. Lagos del Country, Tepic, Nayarit, México.

Universidad de Guadalajara, Centro Universitario de los Altos, División de Ciencias Agropecuarias e Ingenierías, Rafael Casillas Aceves 1200, Tepatitlán de Morelos 47620, México.

Universidad Autónoma del Estado de Hidalgo, Instituto de Ciencias de la Salud, Carretera Pachuca-Actopan, San Juan Tilcuautla, 42160 Pachuca, Hidalgo, México.
\end{abstract}

\section{ABSTRACT}

Nopalea cochenillifera (L.) Salm-Dyck is a scarcely studied cactus; its characterization contributes to identify the bioactive compounds it contains and its functional properties, which will allow the generation of information on potential uses and applications. The aim of this work was to physicochemically characterize $N$. cochenillifera cladodes flour and identify the phenolic compounds it contains. In general, $N$. cochenillifera flour is low in calories (337 kcal/100 g) with high total dietary fiber content (18.41\%). In addition, it exhibits good water (11.04\%) and oil (2.05\%) absorption capacity, while swelling capacity was $25 \mathrm{~mL} / \mathrm{g} \mathrm{DW}$. The soluble and hydrolyzable polyphenols content were 207.92 and $647.99 \mathrm{mg}$ EAG/100 g DW, respectively. In addition, they showed antioxidant activity by DPPH' (15.28 mmol TE/g DW), FRAP (20.97 mmol TE/g DW), and ABTS++ (51.31 mmol TE/g DW) methods. Furthermore, six phenolic acids (gallic, ferulic, chlorogenic, p-coumaric, syringic, and neochlorogenic) were identified by HPLC. According to the results, N. cochenillifera cladodes flour is an important source of fiber and bioactive compounds with interesting functional properties. In this context, N. cochenillifera flour could be used as an ingredient in the formulation of functional foods. However, further, studies are needed on the shelf life and optimizing its preservation process, transformation, and functional potential.

Keywords: Nopalea cochenillifera (L.) Salm-Dyck, antioxidant capacity, dietary fiber, bioactive compounds, physicochemical characterization.

\section{RESUMEN}

Nopalea cochenillifera (L.) Salm-Dyck es un nopal poco estudiado, su caracterización contribuye a identificar los compuestos bioactivos y las propiedades funcionales que posee, esto permitirá, generar información sobre potenciales usos y aplicaciones. El objetivo del trabajo fue caracterizar

Volumen XXIV, Número 1 fisicoquímicamente la harina de cladodios de N. cochenillifera e identificar los compuestos bioactivos que contiene. En general, la harina de $N$. cochenillifera tiene bajas calorías (337 $\mathrm{kcal} / 100 \mathrm{~g}$ ) con alto contenido de fibra dietética (18.41\%). Además, exhibe buena capacidad de absorción de agua (11.04\%) y aceite $(2.05 \%)$, mientras que la capacidad de hinchamiento fue de $25 \mathrm{~mL} / \mathrm{g}$ base seca (bs). El contenido de fenoles solubles y polifenoles hidrolizables fueron 207.92 y $647.99 \mathrm{mg}$ EAG/100 g bs respectivamente. Además, de presentar actividad antioxidante por DPPH' $(15.28 \mathrm{mmol}$ TE/g bs), FRAP (20.97 mmol TE/g bs) y ABTS++ $(51.31 \mathrm{mmol}$ $\mathrm{TE} / \mathrm{g}$ bs), se identificaron cinco ácidos fenólicos. De acuerdo con los resultados, la harina de $N$. cochenillifera es una fuente importante de fibra y compuestos bioactivos con propiedades funcionales. En este contexto, podría ser utilizada como ingrediente funcional en la formulación de otros alimentos. Sin embargo, son necesarios futuros estudios sobre la vida útil de la harina, así como la optimización de su proceso de conservación, transformación y potencial funcional.

Palabras clave: Nopalea cochenillifera (L.) Salm-Dyck, Capacidad antioxidante, fibra dietética, Compuestos bioactivos, Caracterización fisicoquímica

\section{INTRODUCTION}

Currently, there is a trend to consume foods that are low in carbohydrates but high in dietary fiber, as well as those containing functional ingredients. Fiber consumption has been associated with health benefits for modulating the intestinal microbiota. In addition, it regulates blood glucose and lipid (cholesterol and triglycerides) levels, contributing to the control and prevention of non-transmissible chronic diseases such as diabetes, dyslipidemias, and obesity (Holscher, 2017; Ríos-Hoyo et al., 2017; Weickert and Pfeiffer, 2018).

In the literature, fresh nopal cactus is described as a vegetable with high water (88-95\%) and carbohydrate (3-7

*Autor para correspondencia: Juan Pablo Hernández Uribe Correo electrónico: juan_hernandez8391@uaeh.edu.mx

Recibido: 4 de junio de 2021

Aceptado: 16 de octubre de 2021 
g) content, low protein $(0.5-1 \mathrm{~g})$, lipid $(0.2 \mathrm{~g})$, and calorie (27 $\mathrm{kcal} / 100 \mathrm{~g}$ ) content (Sánchez-Tapia et al., 2017; Stintzing and Carle, 2005; Inglese et al., 2018). In addition, it contains bioactive compounds such as polyphenols, which have antioxidant activity. It has been reported that these compounds present in nopal decrease metabolic endotoxemia, glucose intolerance, lipogenesis and metabolic inflexibility (Sánchez-Tapia et al., 2017). According to several authors, the nutritional composition and concentration of bioactive compounds in nopal cactus depends on environmental conditions, species, maturity stage, harvesting season, and/or post-harvest treatments (El-Mostafa et al., 2014; Guevara-Figueroa et al., 2010; Nuñez-López et al., 2013). In Mexico, nopal cactus is consumed fresh (in salads) and the nopal flour is used with other ingredients in a variety of traditional culinary dishes including juices, snacks, and tortillas (Rodríguez-García et al., 2007; Saenz, 2000). Furthermore, it has been used in traditional medicine due to its anti-inflammatory and antimicrobial properties, as well as hypoglycemic activity attributed to the presence of bioactive compounds and dietary fiber (Díaz et al., 2017; NECCHI et al., 2012; Young et al., 2005). Furthermore, over 125 nopal species have been identified in Mexico, where the most commercialized variety is Opuntia, while $N$. cochenillifera (L. Salm-Dyck) is one of the least exploited (Inglese et al., 2018).

Native of Mexico, N. cochenillifera is endemically distributed across Central America. It can reach a height of 3-6 $\mathrm{m}$ and is widely adapted to extreme weather conditions, although its maturation takes longer in cold climates (Scheinvar, 2004). It is considered a wild species, mostly grown in gardens and backyards and used in landscaping, as forage, and/or hedgerows (Lim, 2012). Cladodes are edible, narrow $(4-7 \mathrm{~cm})$, and long $(20-30 \mathrm{~cm})$; they show a few spines on the bark as compared to other species (Beccaro et al., 2015; Scheinvar, 2004). N. cochenillifera, grown all year round and commonly sold locally, and despite having commercial potential, it is undervalued since it is unknown in other markets, especially those far from the cultivation areas (Reyes-Agüero and Aguirre-Rivera, 2016). There is scarce information on the physicochemical and nutritional characterization of the species as well as that of its bioactive compounds and their potential uses. In addition, it has been reported that nopal flours have been used as a food supplement in the production of doughs and bakery products, in order to increase their functional properties (Ayadi et al., 2009; Nabil et al., 2020). Therefore, the objective of this work was to physicochemically characterize $N$. cochenillifera cladodes flour and identify the phenolic compounds that it contains.

\section{MATERIALS AND METHODS Raw material}

The cladodes from $N$. cochenillifera were manually and randomly harvested in the Valley region of Tulancingo, Hidalgo, Mexico. The cladodes were used at commercial maturity, considering the following morphometric variables: $25 \mathrm{~cm}$ length, $6 \mathrm{~cm}$ width, and $1 \mathrm{~cm}$ thickness.

\section{Sample preparation}

Three batch cladodes with spines were selected according to the provisions in the Codex Alimentarius (Codex, 2017). First, spines were removed manually, and cladodes were washed with distilled water and disinfected with a $\mathrm{NaClO}$ solution $(4.5 \mathrm{mg} / \mathrm{L})$. Next, cladodes were cut into strips (10 cm long, $1 \mathrm{~cm}$ wide), then dried at $45{ }^{\circ} \mathrm{C}$ for $48 \mathrm{~h}$ in a convection oven (3489M-1, Barnstead International, Dubuque, lowa, US), ground in a mill (UDY Cyclone Sample Mill), and sieved through a 100-mesh screen (US). Finally, powder samples stored in airtight polyethylene bags at room temperature and darkness until analysis.

\section{Proximal analysis}

Moisture (method 934.06), total soluble solids (method 932.12), protein (method 978.04), ashes (method 940.26), and lipids (method 950.54) were quantified using the official methods in AOAC (2012). Total carbohydrates were calculated by difference (equation 1), while energetic value was estimated using the equation (2) proposed by Nabil et al. (2020).

Total carbohydrates $(\mathrm{g} / 100 \mathrm{~g})=100$ - (lipids + ash + proteins $)$

Energy $(\mathrm{Kcal} / 100 \mathrm{~g})=4 *$ (proteins + carbohydrates $)+9 *$ (lipids)

\section{Dietary fiber}

Dietary fiber (DF) was assessed by the enzymaticgravimetric method with modifications by Mañas and Saura-Calixto (1995). First, samples $(0.5 \mathrm{~g})$ mixed with 25 $\mathrm{mL}$ of phosphate buffer $(0.08 \mathrm{M}, \mathrm{pH} 6)$ was heated at 100 ${ }^{\circ} \mathrm{C}$ for $5 \mathrm{~min}$, and then treated with $25 \mu \mathrm{L}$ of thermostable a-amylase (A-3306, Sigma Chemical Co., St Louis MO, US) at $100{ }^{\circ} \mathrm{C} / 35 \mathrm{~min}$, after that, samples were cooled at ambient temperature. Furthermore, the $\mathrm{pH}$ of the solution was adjusted at 7.5 with $\mathrm{NaOH}(1 \mathrm{~N})$; next, $50 \mu \mathrm{L}$ of protease (Sigma Chemical Co., St Louis MO, US Sigma, P-5380 at $50 \mathrm{mg} / \mathrm{mL}$ of phosphate buffer) were added, and samples incubated in a water bath at $60{ }^{\circ} \mathrm{C} / 35 \mathrm{~min}$, and cooled at ambient temperature. The $\mathrm{pH}$ was adjusted at 4.5 with $\mathrm{HCl}(1 \mathrm{~N})$, and 150 $\mu \mathrm{L}$ of $\beta$-amyloglucosidase (Sigma Chemical Co., St Louis MO, US Sigma, A-9913) were added, and the solution was heated again at $60^{\circ} \mathrm{C} / 35 \mathrm{~min}$. Finally, the solution was centrifuged using a high-speed centrifuge (BKC-TH21RL, Biobase, Shandong (hina) at $3000 \times$ g, $25^{\circ} \mathrm{C}$, for $15 \mathrm{~min}$, to separate the soluble and insoluble fractions. The supernatants collected from the centrifugation were dialyzed (D-9652, $33 \mathrm{~mm}$, $12400 \mathrm{Da}$, Sigma Aldrich) against deionized water for $24 \mathrm{~h}$. The supernatants were dialyzed against water to prevent the loss of soluble dietary fiber (SDF). The dialysates containing SDF $(17 \mathrm{~mL})$ were acid hydrolyzed $\left(12 \mathrm{M} \mathrm{H}_{2} \mathrm{SO}_{4}\right)$ and incubated in water bath at $100{ }^{\circ} \mathrm{C}$ for $90 \mathrm{~min}$. The SDF content was calculated using the method proposed by Englyst and Cummings (1988), using 3,5 dinitrosalicylic acid and glucose as standard at $530 \mathrm{~nm}$. On the other hand, residues (insoluble dietary fiber, IDF) previously oven-dried were subject to acid hydrolysis $\left(3 \mathrm{~mL}\right.$ of $12 \mathrm{M} \mathrm{H}_{2} \mathrm{SO}_{4}$ in a water bath at $37^{\circ} \mathrm{C}$ for 1 
h), followed by the addition of $33 \mathrm{~mL}$ of distilled water and kept in a water bath $\left(100^{\circ} \mathrm{C}\right.$ for $\left.90 \mathrm{~min}\right)$. Finally, the solution was centrifuged $\left(6000 \times \mathrm{g}, 25^{\circ} \mathrm{C}, 15 \mathrm{~min}\right)$ and supernatant was recovered. The IDF content was quantified using DNS reagent at $530 \mathrm{~nm}$, as previously described. The remaining residues of IDF were quantified as Klason lignin (KL) by gravimetric method. IDF was calculated as NSP plus KL, while the total dietary fiber content was the sum of SDF and IDF.

\section{pH}

The $\mathrm{pH}$ was assessed with a digital potentiometer $(\mathrm{HI}$ $2211 \mathrm{PH} / \mathrm{MV}$, HANNA) calibrated before the measurement with reference buffer solutions ( $\mathrm{pH} 4.0$ and 7.0), according to AOAC (2012), based on the immersion of an electrode in the solution. The sample $(1 \mathrm{~g})$ was mixed in $10 \mathrm{~mL}$ distilled water for analysis, and the reading was recorded.

\section{Color attributes}

The color was quantified using a colorimeter (CR-410, Konica Minolta, Sensing Inc., Osaka, Japan) previously calibrated. Results were expressed according to the rectangular coordinate system $L^{*} a^{*} b^{*}$.

\section{Apparent density}

The apparent density was determined using the method reported by Kaur and Singh (2005). Density was calculated in a graduated cylinder previously tared with 10 $\mathrm{mL}$ of the sample, and the sample weight was calculated as grams per volume unit $(\mathrm{g} / \mathrm{mL})$.

\section{Water solubility index and water absorption capacity}

The water solubility index (WSI) and the water absorption capacity (WAC) analysis were performed following the methodology proposed by Anderson et al. (1969), with minor modifications. The sample $(2.5 \mathrm{~g})$ was homogenized with $30 \mathrm{~mL}$ distilled water, kept at $30^{\circ} \mathrm{C}$ in a water bath for $30 \mathrm{~min}$, and then centrifuged using a high-speed centrifuge (BKC-TH21RL, Biobase, Shandong China) at $3000 \times$ g/30 min. The supernatant was decanted and oven-dried (3489M-1, Barnstead International, Dubuque, lowa, US) at $90^{\circ} \mathrm{C}$ for 24 h. Additionally, the pellet weight was recorded, and WSI and WAC were calculated with equation 3 and 4, respectively. The results of WSI are expressed in percentage, and WAC as $g$ of retained water per $\mathrm{g}$ dry weight.

$$
W S I(\%)=\frac{\text { Weight of dry solids in supernatant }}{\text { Weight of dry sample }} * 100
$$

$$
\begin{aligned}
& \text { And } \\
& W A C=\frac{\text { Residue weight, which contained the water }(\mathrm{g})}{\text { Original weight of cladodes flour }(\mathrm{g})}
\end{aligned}
$$

\section{Oil absorption capacity}

Oil absorption capacity (OAC) was assessed following the methodology by Anderson et al. (1969) with minor modifications. The sample $(2.5 \mathrm{~g})$ was mixed with $30 \mathrm{~mL}$ common corn oil in a 50-mL conical tube, shaken in a vortex for $1 \mathrm{~min}$ and then centrifuged using a high-speed centrifuge
(BKC-TH21RL, Biobase, Shandong China) at $3000 \times$ g/30 min, and the supernatant was decanted. The pellet weight was recorded, the OAC was calculated using the equation (5), and results expressed as $\mathrm{g}$ of oil retained per $\mathrm{g}$ of sample.

$$
O A C=\frac{\text { residue weight, which contained the oil }(\mathrm{g})}{\text { Original weight of cladodes flour }(\mathrm{g})}
$$

\section{Swelling capacity}

The swelling capacity (SC) was determined using the method described by Robertson et al. (2000). The sample (100 $\mathrm{mg}$ ) was hydrated with $10 \mathrm{~mL}$ distilled water in a calibrated cylinder ( $1.5 \mathrm{~cm}$ diameter) at room temperature. Then, after equilibration (18 h), the volume occupied by sample was recorded and expressed as volume per $\mathrm{g}$ dry weight.

\section{Total soluble polyphenols, hydrolyzable polyphenols, and condensed tannins quantification}

According to the methodology by Pérez-Jiménez et al. (2008), an organic-aqueous extraction was performed to quantify the different compounds. The sample $(0.5 \mathrm{~g})$ was mixed with $20 \mathrm{~mL}$ methanol-acidified water solution $(0.8 \%$ $\mathrm{HCl} 72.8 \mathrm{~g} / \mathrm{L}$ ). The mixture was stirred at room temperature at a moderate speed $(10 \times \boldsymbol{g}$ for $1 \mathrm{~h}$ ) in a shaker (Heidolph Rex 2, Heidoplh Instruments, Schuwabach, Germany) and then centrifuged at $8000 \times g$ for $10 \mathrm{~min}$ at $4{ }^{\circ} \mathrm{C}$. Next, the recovered supernatants and the residues were mix with acetone-water solution ( $20 \mathrm{~mL}, 80: 20 \mathrm{v} / \mathrm{v})$, stirred for $1 \mathrm{~h}$ at room temperature and centrifuged under described conditions. Both supernatants were combined to measure soluble phenols (at $750 \mathrm{~nm}$ ) by the Montreau (1972) procedure, using the Folin-Ciocalteu reagent, and the results expressed as milligrams of gallic acid equivalent per $100 \mathrm{~g}$ dry weight (mg EAG/100 $\mathrm{g}$ DW), with a standard curve of gallic acid. The residues of the extraction were used to quantify non-extractable polyphenols (NEP) made up of hydrolyzable polyphenols (HP) and condensed tannins (CT). The determination of HP was according to the method proposed by Hartzfeld et al. (2002). The residues obtained from the organic-aqueous extraction were hydrolyzed with $20 \mathrm{~mL}$ methanol $/ \mathrm{H}_{2} \mathrm{SO}_{4^{\prime}} 90: 10(\mathrm{v} / \mathrm{v})$ at $85^{\circ} \mathrm{C}$ for $20 \mathrm{~h}$, and then centrifuged using a high-speed centrifuge (BKC-TH21RL, Biobase, Shandong China) at $3000 \times g$ at $25^{\circ} \mathrm{C}$ for $15 \mathrm{~min}$, to assess HP in the supernatants using the Folin-Ciocalteu reagent as previously described. The CT were analyzed in the extraction residues, which were hydrolyzed with $10 \mathrm{~mL}$ butanol- $\mathrm{HCl}-\mathrm{FeCl}_{3}\left(100{ }^{\circ} \mathrm{C}, 3 \mathrm{~h}\right)$ and centrifuged using a high-speed centrifuge (BKC-TH21RL, Biobase, Shandong (hina) at $8000 \times$ g, for 10 min, to recover supernatants, and absorbance was measure at $555 \mathrm{~nm}$, according to Reed et al. (1982). CT were calculated using a standard curve of proanthocyanidins from Mediterranean carob pods (Ceratonia siliqua L.), and the $\mathrm{CT}$ content expressed as $\mathrm{mg} / \mathrm{g}$ DW. The quantification of total phenolic compounds was determined with the sum of soluble polyphenols (TSP) and hydrolysable phenols. A multi-mode microplate reader (Synergy HT, Biotek Instruments Inc., Winooski, Vermont, US) was used to quantify soluble and hydrolysable phenols. 


\section{Antioxidant activity}

The antioxidant capacity of the organic aqueous extracts was quantifying 2,2'-azino bis (3-ethylbenzothiazoline-6-sulfonic acid) (ABTS+) radical cation scavenging activity, analyzed using a modified version of the methodology by Re et al. (1999). The radical cation was prepared by mixing $19.3 \mathrm{mg}$ of $\mathrm{ABTS}^{+}(7 \mathrm{mM})$ in $5 \mathrm{~mL}$ of potassium persulfate $(2.45$ $\mathrm{mM}$ ) and stored (12-16 h) in the dark at room temperature under magnetic stirring. The ABTS ${ }^{+}$solution was adjusted with phosphate buffer $(0.1 \mathrm{M}, \mathrm{pH} 7.4)$ to an absorbance of 0.7 $( \pm 0.02)$ at $734 \mathrm{~nm}$. The Trolox (6-hydroxy-2,5,7,8-tetramethylchroman-2carboxylic acid) was used as a standard and methanol as a blank. Sample ( $30 \mu \mathrm{L}$ ) was mixed with $255 \mu \mathrm{L}$ ABTS ${ }^{+}$ $\left(30^{\circ} \mathrm{C}\right.$ for $7 \mathrm{~min}$ ). The reduction in absorbance was measured at $734 \mathrm{~nm}$. The scavenging of 1,1-diphenyl-2-picrylhydrazyl (DPPH) radicals was performed according to Prior et al. (2005) with some modifications. The Trolox sample or standard (30 $\boldsymbol{\mu} \boldsymbol{L})$ reacted with $200 \mu \mathrm{L}$ DPPH' solution $(190 \mu \mathrm{M}$, using methanol as dissolvent) while absorbance was measured at 517 $\mathrm{nm}$ after $10 \mathrm{~min}$. The ferric reducing antioxidant power assay (FRAP) was carried out following the methods by Benzie and Strain (1996), with modifications. The FRAP solution, 10:1:1 $(\mathrm{v} / \mathrm{v} / \mathrm{v})$ of sodium acetate buffer $(0.3 \mathrm{M}, \mathrm{pH} 3.6), 10 \mathrm{mM}$ TPTZ (2,4,6-tripiridyls-triazine), and $20 \mathrm{mM}$ iron chloride hexahydrate, was tempered to $37^{\circ} \mathrm{C}$ before mixing with the samples. The extract of the sample $(24 \mu \mathrm{L})$ or Trolox standard was added to a 96-well microplate, then mixed with $180 \mu \mathrm{L}$ FRAP solution using a multichannel dispenser, and the absorbance measured at $595 \mathrm{~nm}$ after $30 \mathrm{~min}$. A multi-mode microplate reader (Synergy HT, Bio-Tek, Instrument Inc., Winooski, Vermont, US) was used to quantify the antioxidant activity of described methods. All the methods of antioxidant capacity and results were expressed as mmol Trolox equivalent per $\mathrm{g}$ dry weight ( $\mathrm{mmol} \mathrm{TE} / \mathrm{g} \mathrm{DW}$ ).

\section{Carotenoid content}

The sample carotenoids were determined according to Ortega et al. (2013). Two $\mathrm{g}$ of sample were mixed with $7 \mathrm{~mL}$ of acetone:petroleum ether $80: 20(\mathrm{v} / \mathrm{v})$ and $0.5 \mathrm{~g}$ of $\mathrm{MgCO}_{3^{\prime}}$ then homogenized for $1 \mathrm{~min}$ before centrifuged using a high-speed centrifuge (BKC-TH21RL, Biobase, Shandong China) at $15000 \mathrm{rpm}$ for 30 minutes at $4{ }^{\circ} \mathrm{C}$. The supernatant was placed in a separator funnel adding $15 \mathrm{~mL}$ of $\mathrm{NaCl}(20 \%)$, the aqueous phase drained, and the organic layer diluted to $10 \mathrm{~mL}$ with petroleum ether. Absorbance was measured at $448 \mathrm{~nm}$ using a UV/Vis spectrophotometer (Jenway model 6705). The quantification was performed using a $\boldsymbol{\beta}$-carotene calibration curve, and the results expressed as $\mathrm{mg} \beta$-carotene per $100 \mathrm{~g}$ dry weight.

\section{Quantification of phenolic acids by HPLC}

The identification of phenolic acids was performed in an HPLC system (1260 Infinity, Agilent Technologies, Waldbron, Germany) equipped with photodiode-array detection and a C18 reversed phase column (particle size 5 $\mu \mathrm{m}$, diameter $4.6 \mathrm{~mm}$, and length $250 \mathrm{~mm}$, Thermo Scienti- $\mathrm{fic}^{\oplus}$, Sunnyvale, California, US). The mobile phases were $2 \%$ acidified water with acetic acid (eluent $A$ ) and acidified water (0.5\% acetic acid): methanol 10:90 (eluent B). The standards and extracts of the sample were analyzed using a $0 \% \mathrm{~B}$ gradient; 0-35 min, 35\% B; 35-55 min, 75\% B; 55-60 min, 100\% $\mathrm{B}$; and $60-70 \mathrm{~min}, 0 \% \mathrm{~B}$, at a flow rate of $0.4 \mathrm{~mL} / \mathrm{min}$. The peak areas were detected at 280 and $320 \mathrm{~nm}$ for the sample and calibration curve $(0.5-300 \mu \mathrm{g} / \mathrm{mL})$ of gallic, ferulic, chlorogenic, p-coumaric, syringic, and neochlorogenic acids (SigmaAldrich, Inc., St. Louis, Missouri, US), were used to identify and quantify the polyphenolic compounds (Jiménez et al., 2014).

\section{Statistical analysis}

All results were expressed as mean values \pm standard deviation. Data were analyzed using Sigma-Stat version 11. All the analytical measurements were done in triplicate on a same batch of nopal flour, nine determinations were made.

\section{RESULTS AND DISCUSSION Proximal analysis}

Table 1 shows the nutritional composition of the $N$. cochenillifera flour. The moisture content (4.6\%) is adequate for storage, which reduces the enzymatic reactions and/or presence of microorganisms (Rodríguez-García et al., 2007). Moreover, the lipid (1.20\%) and protein (6.44\%) contents were lower than those reported in Opuntia ficus-indica flour (lipid 2.3\% and protein 8.76\%), while the total carbohydrates (75.16\%) and ashes (17.2\%) in N. cochenillifera were higher than those reported (Nabil et al., 2020) in Opuntia ficus-indica (74.27\% carbohydrates and $11.90 \%$ ashes respectively). Additionally, the caloric contribution of cladodes flour was of $337 \mathrm{kcal} / 100 \mathrm{~g}$, while higher values has been reported for commercial flours from corn and wheat $(397.68 \mathrm{kcal} / 100 \mathrm{~g}$ and $384.2 \mathrm{kcal} / 100 \mathrm{~g}$, respectively) (Kavitha and Parimalavalli, 2014).

The consumption of dietary fiber associates to beneficial effects on consumers' health (Holscher, 2017).

Table 1. Nutritional composition of N. cochenillifera cladodes flour. Tabla 1. Composición nutricional de la harina de cladodios de $N$. cochenillifera.

\begin{tabular}{ll}
\hline Parameter & Cladodes flour \\
\hline Moisture (g/100 g dry weight) & $4.6 \pm 0.06$ \\
\hline Protein (g/100 g dry weight) & $6.44 \pm 0.82$ \\
\hline Lipid (g/100 g dry weight) & $1.20 \pm 0.04$ \\
\hline Carbohydrate (g/100 g dry weight) & $75.16 \pm 0.97$ \\
\hline Ash (g/100 g dry weight) & $17.2 \pm 0.11$ \\
\hline Energy (Kcal/100 g dry weight) & $337.2 \pm 1.83$ \\
\hline Total dietary fiber (g/100 g dry weight) & $18.41 \pm 0.05$ \\
\hline Insoluble dietary fiber (g/100 g dry weight) & $16.92 \pm 0.19$ \\
\hline Soluble dietary fiber (g/100 g dry weight) & $1.49 \pm 0.21$ \\
\hline
\end{tabular}

All values are means \pm standard deviation of three determinations per batch. 
The total dietary fiber content in N. cochenillifera flour was $18.41 \%$ ( $16.92 \%$ insoluble and $1.49 \%$ soluble), similar to that reported by Stintzing and Carle (2005), who found the average content of fiber in dehydrated Opuntia was $18 \%$. Additionally, reports show that the amount of soluble fiber decreases as cladode ages, while insoluble fiber increases (Nabil et al., 2020; Rodríguez-García et al., 2007). The low soluble fiber content in $N$. cochenillifera may associate to the drying temperature $\left(45^{\circ} \mathrm{C}\right)$ during cladodes flour processing, which is the same as that of the glass transition of mucilage, promoting soft-flexible to rigid state and solubility changes, leading to possible hydrolysis (Ventura-Aguilar et al., 2017). According to the World Health Organization, the recommended fiber dietary intake (RDI) is an average of $25 \mathrm{~g} /$ day for both men and women; therefore, adding $15 \mathrm{~g}$ of $\mathrm{N}$. cochenillifera flour to food products could contribute to at least $10 \%$ of the RDI. Subsequently, N. cochenillifera flour is a potential source of dietary fiber and its consumption could prevent and control non-transmissible chronic diseases (Bchir et al., 2014). Furthermore, previous reports show that both soluble and insoluble nopal fiber has therapeutic effect on irritable bowel syndrome when nopal when consumed at a $20 \mathrm{~g} /$ day dose (Remes-Troche et al., 2021). In this context, it is feasible the use $N$. cochenillifera flour as a functional ingredient in products with low caloric and high dietary fiber contents.

\section{Physicochemical properties}

Table 2 shows $\mathrm{pH}$, total soluble solids, and color attributes of cladodes flour that showed a pH of 5.1, consistent with $\mathrm{pH}$ reported by Sáenz and Berger (2006), who found $\mathrm{pH}$ values from 4.0 to 7.0 in Opuntia flours. The total soluble solids in the flour were 6.9 Brix, possibly associated with $N$. cochenillifera soluble sugar (glucose) content (Nabil et al., 2020). On the other hand, the color parameters if luminosity $\left({ }^{*} \mathrm{~L}\right)$, reddening $(\mathrm{a})$, and yellowing (b) of cladodes flour were $67.62,-3.47$, and 18.2 , respectively, indicating that the flour exhibited a yellow, pale green color, similar to that reported in O. ficus-indica powder (Sáenz et al., 2010). The N. cochenillifera cladodes flour apparent density was $0.6 \mathrm{~g} / \mathrm{mL}$, similar to the reports on spineless $O$. ficus indica $f$. inermis cladodes powders (Ayadi et al., 2009). This parameter relates to dietary fiber content; insoluble fiber content (mostly insoluble cellulose and hemicellulose) or soluble fiber fraction (mainly mucilages and pectins), which could modify powder density (Nuñez-López et al., 2013).

\section{Functional properties}

The WSI relates to the presence of soluble molecules in the flour. The cladodes flour WSI was 5.4; powdered spineless cladodes have shown a higher WSI as compared against spine-covered cladodes (Ayadi et al., 2009). The WAC is a property linked to water retention within a matrix, which largely depends on the physicochemical nature of the flour fiber fraction; it directly affects the technological and functional properties of the flour. The cladodes flour WAC value was $11.4 \mathrm{~g}$ of water/g DW, which relates to the water retention
Table 2. Physicochemical parameters and functional properties of N. cochenillifera cladodes flour.

Tabla 2. Parámetros fisicoquímicos y propiedades funcionales de la harina de cladodios de N. cochenillifera.

\begin{tabular}{lc}
\hline Parameter & Cladodes flour \\
\hline $\mathrm{pH}$ value & $5.1 \pm 0.06$ \\
\hline Total soluble solids ( ${ }^{\circ} \mathrm{Bx}$ ) & $6.9 \pm 0.02$ \\
\hline $\mathrm{L}^{*}$ & $67.62 \pm 0.01$ \\
\hline $\mathrm{a}^{*}$ & $-3.47 \pm 0.02$ \\
\hline $\mathrm{b}^{*}$ & $18.20 \pm 0.01$ \\
\hline Bulk density (g/ml) & $0.6 \pm 0.0$ \\
\hline Water solubility index (\%) & $5.4 \pm 0.85$ \\
\hline Water absorption capacity (g water/g dry weight) & $11.4 \pm 0.03$ \\
\hline Oil absorption capacity (g of oil/g dry weight) & $2.05 \pm 0.05$ \\
\hline Swelling capacity (mL/g dry weight) & $25.0 \pm 0.02$ \\
\hline
\end{tabular}

All values are means \pm standard deviation of three determinations per batch.

capacity due to hydrophilic components in its matrix. $N$. cochenillifera showed a higher WAC value (11.4 g of water/g DW) than that reported in Opuntia (8 $\mathrm{g}$ of water/g DW) (Ayadi et al., 2009; Nuñez-López et al., 2013). Furthermore, its WAC was higher than those reported for flours made from apples, pears, and carrots; which showed WAC ranging from 1 to $8 \mathrm{~g}$ of water/g DW (Ahmad et al., 2016).

On the other hand, the OAC is a relevant parameter to evaluate the hydrophobic nature of the particles that constitute the fiber fraction in the flour (Ventura-Aguilar et al., 2017). N. cochenillifera powder showed an OAC of $2.05 \mathrm{~g}$ of oil/g DW, comparable to the same OAC value in flours obtained from vegetable sources such as apple and pear (Bchir et al., 2014).

In addition, the SC relates to the dietary fiber content since carbohydrates interact with free polar groups through hydrophilic bonds, retaining them in a matrix. Cladodes flour showed an SC of $25 \mathrm{~mL} / \mathrm{g} \mathrm{DW}$, which suggests that its components can absorb water due to its capacity to form matrices similar to those of a gel. In addition, these properties promote a low diffusion and a higher absorption of lipid compounds or sugars (Nuñez-López et al., 2013).

These characteristics directly affect the cladodes flour technological and functional properties. They could induce beneficial effects in health by significantly increase chyme viscosity in a dose- or amount-dependent manner. This fact leads to a beneficial regularity by altering fecal viscosity since this property determines the speed at which a substrate transits through the large intestine (McRorie Jr and McKeown, 2017).

\section{Biocompound contents and antioxidant capacity}

Table 3 shows the soluble and hydrolyzable polyphenols, tannins, carotenes, and antioxidant activity. The N. cochenillifera flour total phenol content was $207.95 \mathrm{mg}$ GAE/100 g DW, slightly higher than the $180 \mathrm{mg} \mathrm{GAE} / 100 \mathrm{~g}$ 
Table 3. Bioactive compounds content and antioxidant activity of N. cochenillifera cladodes flour

Tabla 3. Contenido de compuestos bioactivos y actividad antioxidante de la harina de cladodios de N. cochenillifera.

\begin{tabular}{lc}
\hline Parameter & Cladodes flour \\
\hline Total soluble phenols (mg GAE/100 g DW) & $207.92 \pm 0.74$ \\
\hline Hydrolysable polyphenols (mg GAE/100 g DW) & $647.99 \pm 3.18$ \\
\hline Condensed tannins (mg/g DW) & $3.55 \pm 0.4$ \\
\hline Carotenes (mg $\beta$-carotene/100 g DW) & $4.36 \pm 0.2$ \\
\hline Antioxidant activity & \\
\hline DPPH' (mmol TE/g DW) & $15.28 \pm 0.4$ \\
\hline FRAP (mmol TE/g DW) & $20.97 \pm 0.5$ \\
\hline ABTS++ (mmol TE/g DW) & $51.31 \pm 4.71$ \\
\hline
\end{tabular}

All values are means \pm standard deviation of three determinations per batch. TE = Trolox equivalent, FRAP = Ferric-reducing antioxidant power assay, $\mathrm{DPPH}^{\cdot}=$ 2,2- diphenyl-1-picrylhydrazyl assay, $\mathrm{ABTS}^{\cdot+}=2$ 2,-azinobis-3-ethylbenzothiazoline-6-sulfonic acid assay, DW = Dry weight, GAE = Gallic acid equivalent.

DW reported by Gallegos-Infante et al. (2009) in O. ficus-indica cladodes flour. The difference between these values may relate to the drying process, since previous work showed that different airflow rates and temperatures, modify total phenols (Medina-Torres et al., 2011). The content of hydrolyzable polyphenols in N. cochenillifera flour was $647.99 \mathrm{mg} \mathrm{GAE} / 100$ $\mathrm{g}$ DW. The hydrolyzable forms include a larger proportion of the polyphenols present in $N$. cochenillifera flour than the soluble polyphenols, as previously shown.

On the other hand, tannins are high-molecular-weight polyphenols beneficial to health. Their monomer structure classifies them into two groups: hydrolysable tannins formed by phenolic acids and condensed tannins (Chung et al., 1998). The latter showed values of $3.55 \mathrm{mg} / \mathrm{g}$ DW in N. cochenillifera, which depends on the maturity of the cladodes (FigueroaPérez et al., 2018). Another activity evaluated in Carotenes, is their antioxidant activity, since they are very efficient physical quenchers of singlet oxygen and scavengers of other reactive oxygen species (Fiedor and Burda, 2014). The $N$. cochenillifera cladodes flour carotene content $(4.36 \mathrm{mg}$ $\beta$-carotene/100 g DW) was higher than that reported for Opuntia cladodes (3.79 mg/100 g DW) subjected to heat treatments. There are reports showing that the extraction of nopal carotenes depends on the presence of mucilage, since these compounds can form complexes with pectin, thus the use of high temperatures for their extraction are necessary (Sáenz et al., 2010, Saenz, 2006; Jaramillo-Flores et al., 2003).

The N. cochenillifera cladodes flour antioxidant activity, assessed with DPPH', FRAP, and ABTS'+, was 15.28, 20.97, and $51.31 \mathrm{mmol}$ TE/g DW, respectively. The highest antioxidant activity value may relate to the $N$. cochenillifera cladodes flour high polyphenols content. In contrast, the low tannins and carotenes content may influence the lowest value, reported previously, showing that polyphenols significantly correlate with $\mathrm{ABTS}^{+}$assays, while tannins with $\mathrm{DPPH}^{\cdot}$ assays (Figueroa-Pérez et al., 2018). Additionally, the antioxidant capacity shown with FRAP could be mainly due to the tannins and carotenes content, since these compounds are very efficient at controlling singlet oxygen, and phenolic compounds can sequester free radicals and electron transfer $\left(\mathrm{ABTS}^{+}\right)$better (Koracevic et al., 2001; Pertuzatti et al., 2014).

\section{Polyphenol profile}

The $N$. cochenillifera cladodes flour phenolic compounds (gallic, ferulic, chlorogenic, $\mathrm{p}$-coumaric, syringic, and neochlorogenic) content detected by HPLC, are shown in Table 4 and Figure 1. According to soluble polyphenols chromatographic profile, multiple unidentified peaks are shown, which could correspond to phenolic compounds that have been reported by Figueroa-Perez et al. (2018), who identified 15 phenolic acids compounds in nopal cladodes at different maturity stages, from which only 11 were previously identified in commercial and wild Opuntia spp. (Guevara-Figueroa et al., 2010). Considering the diversity of phenolic compounds reported in other nopal varieties, the unidentified peaks in the $N$. cochenillifera phenolic profile, may include salicylic, protocatechuic, 4-Hydroxybenzoic, vanillic, caffeic, synaptic, eucomic and chlorogenic acids (Astello-García et al., 2015; Figueroa-Pérez et al., 2018; Guevara-Figueroa et al., 2010; Kolniak-Ostek et al., 2020; Mata et al., 2016; Missaoui et al., 2020). Therefore, further studies are necessary to identify $N$. cochenillifera phenolic compounds.

On the other hand, the most abundant phytochemicals identified were gallic, ferulic and chlorogenic acids. The gallic acid content $(2708.49 \mu \mathrm{g} / \mathrm{g})$ indicated in this study was higher than that found by Jun et al. (2013). However, the same author reported that ferulic, chlorogenic and p-coumaric acid contents were higher than the data obtained in this study (796.73, 179.70 and $80.58 \mu \mathrm{g} / \mathrm{g}$, respectively). This difference in the phenolic acid content is likely due to factors such as the cladodes maturity stage, species, geographic conditions, and other environmental conditions (Moussa-Ayoub et al., 2014).

Figueroa-Pérez et al. (2018) observed different polyphenol profiles in nopal (O. fiscus-indica) cladodes collected at different maturity stages, with association to health beneficial effects. For example, chlorogenic acid relates with

Table 4. Soluble polyphenol content of $N$. cochenillifera cladodes flour.

Tabla 4. Contenido de polifenoles solubles de la harina de cladodios de $N$. cochenillifera.

\begin{tabular}{|cccc}
\hline No. & Compound & $\begin{array}{c}\text { Retention } \\
\text { time. }(\mathbf{m i n})\end{array}$ & $\begin{array}{c}\text { Cladodes flour Content } \\
(\boldsymbol{\mu g} / \mathbf{g})\end{array}$ \\
\hline 1 & Gallic accid & 15.65 & $2708.49 \pm 106.59$ \\
\hline 2 & Ferulic acid & 53.71 & $796.73 \pm 1.43$ \\
\hline 3 & Chlorogenic acid & 36.85 & $179.70 \pm 12.51$ \\
\hline 4 & Coumaric acid & 50.05 & $80.58 \pm 12.13$ \\
\hline 5 & Syringic acid & 41.52 & $11.12 \pm 0.56$ \\
\hline 6 & Neochlorogenic acid & 21.21 & $9.52 \pm 0.28$ \\
\hline
\end{tabular}

All values are means \pm standard deviation of three determinations per batch. 


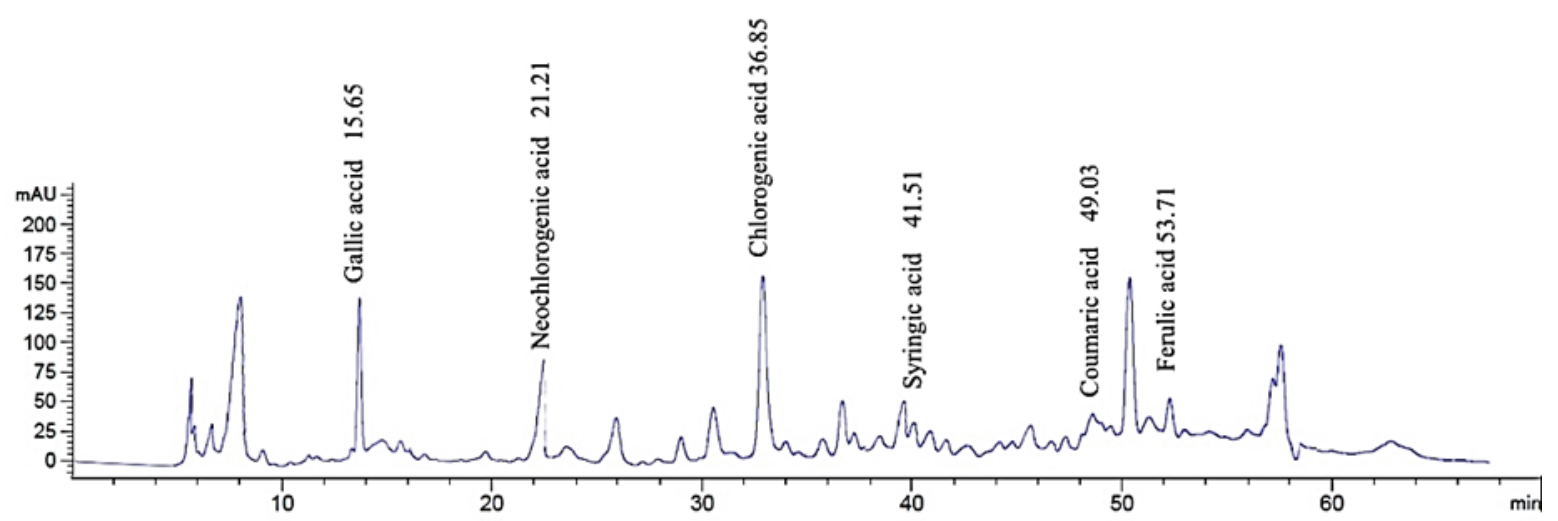

Figure 1. Soluble polyphenols chromatographic profile of $N$. cochenillifera cladodes flour.

Figura 1. Perfil cromatográfico de polifenoles solubles de la harina de cladodios de N. cochenillifera.

antidiabetic effects by delaying intestinal glucose absorption and inhibiting hepatic gluconeogenesis, while gallic acid has shown beneficial effects in the prevention and/or management of various disorders, attributed to its antioxidant potential (Kahkeshani et al., 2019; Ong et al., 2012). These results suggest that $N$. cochenillifera cladodes flour may provide antioxidant properties and offer effective protection from free radicals, and support that $N$. cochenillifera could be a promising source of natural antioxidants.

\section{CONCLUSION}

The results demonstrated that $N$. cochenillifera has similar properties to the Opuntia ficus-indica nopal, and bioactive compounds with antioxidant activity beneficial to the consumers' health. This study is the first step to give an added value to and promote the consumption of this nopal cactus species, which is undervalued in the markets. Furthermore, the cladodes flour phytochemical content and antioxidant activity, makes it a candidate as a functional ingredient in the elaboration of widely used products, such as tortillas and snacks. On the other hand, future studies on the shelf life, optimization, and conservation of cladodes flour are necessary.

\section{ACKNOWLEDGMENTS}

One of the authors (HEFI) acknowledges CONACYTMexico for the scholarship awarded to study the Master in Food Science at the "Instituto de Ciencias de Agropecuarias" (ICAP-UAEH).

\section{CONFLICTS OF INTEREST.}

The authors declare that no conflict of interest exists related with this publication.

\section{REFERENCES}

Ahmad, M., Wani, T. A., Wani, S. M., Masoodi, F. A. and Gani, A. 2016. Incorporation of carrot pomace powder in wheat flour: effect on flour, dough and cookie characteristics. Journal of Food Science and Technology. 53: 3715-3724.
Anderson, R., Conway, H., Pfeifer, V. and Griffin, E. 1969. Roll and extrusion-cooking of grain sorghum grits. Cereal Science Today. 14: 372-376.

AOAC 2012. Official Methods of Analysis, Methods 925.10; 920.87; 920.85 and 923.03, Gaithersburg, MD, U.S.A., AOAC International.

Astello-García, M. G., Cervantes, I., Nair, V., Santos-Díaz, M. D. S., Reyes-Agüero, A., Guéraud, F., Negre-Salvayre, A., Rossignol, M., Cisneros-Zevallos, L. and Barba De La Rosa, A. P. 2015. Chemical composition and phenolic compounds profile of cladodes from Opuntia spp. cultivars with different domestication gradient. Journal of Food Composition and Analysis. 43: 119-130.

Ayadi, M., Abdelmaksoud, W., Ennouri, M. and Attia, H. 2009. Cladodes from Opuntia ficus indica as a source of dietary fiber: Effect on dough characteristics and cake making. Industrial Crops and Products. 30: 40-47.

Bchir, B., Rabetafika, H. N., Paquot, M. and Blecker, C. 2014. Effect of pear, apple and date fibres from cooked fruit byproducts on dough performance and bread quality. Food and Bioprocess Technology. 7: 1114-1127.

Beccaro, G. L., Bonvegna, L., Donno, D., Mellano, M. G., Cerutti, A. K., Nieddu, G., Chessa, I. and Bounous, G. 2015. Opuntia spp. biodiversity conservation and utilization on the Cape Verde Islands. Genetic resources and crop evolution. 62: 21-33.

Benzie, I. F. and Strain, J. J. 1996. The ferric reducing ability of plasma (FRAP) as a measure of "antioxidant power": the FRAP assay. Analytical biochemistry. 239: 70-76.

Chung, K. T., Wong, T. Y., Wei, C. I., Huang, Y. W. and Lin, Y. 1998. Tannins and human health: a review. Crit Rev Food Sci Nutr. 38: 421-64.

Codex, A. 2017. Codex Standard for Nopal Codex Stan 185-1993. In: Organization, F. A. A. O. O. T. U. N. W. H. (ed.) Tropical Fresh Fruits and Vegetables. first ed. Rome, Italy

Diaz, M. D. S. S., De La Rosa, A.-P. B., Héliès-Toussaint, C., Guéraud, F. and Nègre-Salvayre, A. 2017. Opuntia spp.: characterization and benefits in chronic diseases. Oxidative Medicine and Cellular Longevity. 2017:8634249.

El-Mostafa, K., El Kharrassi, Y., Badreddine, A., Andreoletti, P., Vamecq, J., El Kebbaj, M., Latruffe, N., Lizard, G., Nasser, B. and Cherkaoui-Malki, M. 2014. Nopal cactus (Opuntia ficusindica) as a source of bioactive compounds for nutrition, health and disease. Molecules. 19: 14879-14901. 
Englyst, H. N. and Cummings, J. H. 1988. Improved method for measurement of dietary fiber as non-starch polysaccharides in plant foods. Journal of the Association of Official Analytical Chemists. 71: 808-814.

Fiedor, J. and Burda, K. 2014. Potential role of carotenoids as antioxidants in human health and disease. Nutrients. 6: 466488.

Figueroa-Perez, M. G., Perez-Ramirez, I. F., Paredes-Lopez, O., Mondragon-Jacobo, C. and Reynoso-Camacho, R. 2018. Phytochemical composition and in vitro analysis of nopal (O. ficus-indica) cladodes at different stages of maturity. International Journal of Food Properties. 21: 1728-1742.

Gallegos-Infante, J.-A., Rocha-Guzman, N.-E., González-Laredo, R.-F., Reynoso-Camacho, R., Medina-Torres, L. and CervantesCardozo, V. 2009. Effect of air flow rate on the polyphenols content and antioxidant capacity of convective dried cactus pear cladodes (Opuntia ficus indica). International Journal of Food Sciences and Nutrition. 60: 80-87.

Guevara-Figueroa, T., Jimenez-Islas, H., Reyes-Escogido, M. L., Mortensen, A. G., Laursen, B. B., Lin, L.-W., De LeonRodriguez, A., Fomsgaard, I. S. and De La Rosa, A. P. B. 2010. Proximate composition, phenolic acids, and flavonoids characterization of commercial and wild nopal (Opuntia spp.). Journal of Food Composition and Analysis. 23: 525532.

Hartzfeld, P. W., Forkner, R., Hunter, M. D. and Hagerman, A. E. 2002. Determination of hydrolyzable tannins (gallotannins and ellagitannins) after reaction with potassium iodate. Journal of Agricultural and Food Chemistry. 50: 1785-1790.

Holscher, H. D. 2017. Dietary fiber and prebiotics and the gastrointestinal microbiota. Gut microbes. 8: 172-184.

Inglese, P., Mondragon, C., Nefzaoui, A., Saenz, C., Taguchi, M., Makkar, H. and Louhaichi.Mounir 7/10/2018. Ecologia del cultivo, manejo y usos del nopal, Rome Italy, Food and Agriculture Organization of the United Nations (FAO).

Jaramillo-Flores, M. E., Gonzalez-Cruz, L., Cornejo-Mazon, M., Dorantes-Alvarez, L., Gutierrez-López, G. F. and Hernandez-Sanchez, H. 2003. Effect of Thermal Treatment on the Antioxidant Activity and Content of Carotenoids and Phenolic Compounds of Cactus Pear Cladodes (Opuntia ficus-indica). 9: 271-278.

Jiménez, V. M., Gruschwitz, M., Schweiggert, R. M., Carle, R. and Esquivel, P. 2014. Identification of phenolic compounds in soursop (Annona muricata) pulp by high-performance liquid chromatography with diode array and electrospray ionization mass spectrometric detection. Food Research International. 65: 42-46.

Jun, H.-I., Cha, M.-N., Yang, E.-I., Choi, D. G. and Kim, Y.-S. 2013. Physicochemical properties and antioxidant activity of Korean cactus (Opuntia humifusa) cladodes. Horticulture, Environment, and Biotechnology. 54: 288-295.

Kahkeshani, N., Farzaei, F., Fotouhi, M., Alavi, S. S., Bahramsoltani, R., Naseri, R., Momtaz, S., Abbasabadi, Z., Rahimi, R., Farzaei, M. H. and Bishayee, A. 2019. Pharmacological effects of gallic acid in health and diseases: A mechanistic review. Iran J Basic Med Sci. 22: 225-237.

Kaur, M. and Singh, N. 2005. Studies on functional, thermal and pasting properties of flours from different chickpea (Cicer arietinum L.) cultivars. Food chemistry. 91: 403-411.

Kavitha, S. and Parimalavalli, R. 2014. Effect of processing methods on proximate composition of cereal and legume flours. Journal of Human Nutrition and Food Science. 2: 1051.

Kolniak-Ostek, J., Kita, A., Miedzianka, J., Andreu-Coll, L., Legua, P. and Hernandez, F. 2020. Characterization of Bioactive Compounds of Opuntia ficus-indica (L.) Mill. Seeds from Spanish Cultivars. 25: 5734.

Koracevic, D., Koracevic, G., Djordjevic, V., Andrejevic, S. and Cosic, V. 2001. Method for the measurement of antioxidant activity in human fluids. Journal of clinical pathology. 54: 356-361.

Lim, T. K. 2012. Edible medicinal and non-medicinal plants, Springer.

Mañas, E. and Saura-Calixto, F. 1995. Dietary fibre analysis: methodological error sources. European journal of clinical nutrition. 49: S158-S162.

Mata, A., Ferreira, J. P., Semedo, C., Serra, T., Duarte, C. M. M. and Bronze, M. R. 2016. Contribution to the characterization of Opuntia spp. juices by LC-DAD-ESI-MS/MS. Food Chemistry. 210: 558-565.

Mcrorie Jr, J. W. and Mckeown, N. M. 2017. Understanding the physics of functional fibers in the gastrointestinal tract: an evidence-based approach to resolving enduring misconceptions about insoluble and soluble fiber. Journal of the Academy of Nutrition and Dietetics. 117: 251-264.

Medina-Torres, L., Vernon-Carter, E. J., Gallegos-Infante, J. A., Rocha-Guzman, N. E., Herrera-Valencia, E. E., Calderas, F. and Jimenez-Alvarado, R. 2011. Study of the antioxidant properties of extracts obtained from nopal cactus (Opuntia ficus-indica) cladodes after convective drying. Journal of the Science of Food and Agriculture 91: 1001-1005.

Missaoui, M., D'antuono, I., D'imperio, M., Linsalata, V., Boukhchina, S., Logrieco, A. F. and Cardinali, A. 2020. Characterization of Micronutrients, Bioaccessibility and Antioxidant Activity of Prickly Pear Cladodes as Functional Ingredient. 25: 2176.

Montreau, F. 1972. Sur le dosage des composés phénoliques totaux dans les vins par la méthode Folin-Ciocalteu. OENO One. 6: 397-404.

Moussa-Ayoub, T. E., Abd El-Hady, E.-S. A., Omran, H. T., ElSamahy, S. K., Kroh, L. W. and Rohn, S. 2014. Influence of cultivar and origin on the flavonol profile of fruits and cladodes from cactus Opuntia ficus-indica. Food Research International. 64: 864-872.

Nabil, B., Ouaabou, R., Ouhammou, M., Essaadouni, L. and Mahrouz, M. 2020. Functional Properties, Antioxidant Activity, and Organoleptic Quality of Novel Biscuit Produced by Moroccan Cladode Flour "Opuntia ficus-indica". Journal of Food Quality. 2020: 3542398.

Necchi, R. M., Alves, I. A., Alves, S. H. and Manfron, M. P. 2012. In vitro antimicrobial activity, total polyphenols and flavonoids contents of Nopalea cochenillifera (L.) Salm-Dyck (Cactaceae). Research in Pharmacy. 2(3): 01-07.

Nuñez-Lopez, M. A., Paredes-Lopez, O. and Reynoso-Camacho, R. 2013. Functional and hypoglycemic properties of nopal cladodes (O. ficus-indica) at different maturity stages using in vitro and in vivo tests. Journal of agricultural and food chemistry. 61: 10981-10986.

Ong, K. W., Hsu, A. and Tan, B. K. 2012. Chlorogenic acid stimulates glucose transport in skeletal muscle via AMPK activation: a contributor to the beneficial effects of coffee on diabetes. PLoS One. 7: e32718. 
Ortega, V. G., Ramírez, J. A., Velázquez, G., Tovar, B., Mata, M. and Montalvo, E. 2013. Effect of high hydrostatic pressure on antioxidant content of 'Ataulfo' mango during postharvest maturation. Food Science and Technology. 33: 561-568.

Perez-Jiménez, J., Arranz, S., Tabernero, M., Díaz- Rubio, M. E., Serrano, J., Goñi, I. and Saura-Calixto, F. 2008. Updated methodology to determine antioxidant capacity in plant foods, oils and beverages: Extraction, measurement and expression of results. Food Research International. 41: 274285.

Pertuzatti, P. B., Barcia, M. T., Rodrigues, D., Da Cruz, P. N., Hermosín-Gutiérrez, I., Smith, R. and Godoy, H. T. 2014. Antioxidant activity of hydrophilic and lipophilic extracts of Brazilian blueberries. Food Chemistry. 164: 81-88.

Prior, R. L., Wu, X. and Schaich, K. 2005. Standardized methods for the determination of antioxidant capacity and phenolics in foods and dietary supplements. Journal of agricultural and food chemistry. 53: 4290-4302.

Re, R., Pellegrini, N., Proteggente, A., Pannala, A., Yang, M. and Rice-Evans, C. 1999. Antioxidant activity applying an improved ABTS radical cation decolorization assay. Free radical biology and medicine. 26: 1231-1237.

Reed, J. D., Mcdowell, R. T., Van Soest, P. J. and Horvath, P. R. 1982. Condensed tannins: a factor limiting the use of cassava forage. Journal of the Science of Food and Agriculture. 33: 213-220.

Remes-Troche, J. M., Taboada-Liceaga, H., Gill, S., Amieva-Balmori, M., Rossi, M., Hernández-Ramírez, G., García-Mazcorro, J. F. and Whelan, K. 2021. Nopal fiber (Opuntia ficus-indica) improves symptoms in irritable bowel syndrome in the short term: a randomized controlled trial. Neurogastroenterol Motil. 33: e13986.

Reyes-Agüero, J. A. and Aguirre-Rivera, J. R. 2016. Description of the fruit of Nopalea cochenillifera (L.) Salm-Dyck sold in the traditional market of Rioverde, San Luis Potosí, Mexico. Haseltonia. 2016: 43-45.

Rios-Hoyo, A., Romo-Araiza, A., Meneses-Mayo, M. and Guttiérrez-Salmeán, G. 2017. Prehispanic functional foods and nutraceuticals in the treatment of dyslipidemia associated to cardiovascular disease: A mini-review. International journal for vitamin and nutrition research. 87: 58-98.
Robertson, J. A., De Monredon, F. D., Dysseler, P., Guillon, F., Amado, R. and Thibault, J.-F. 2000. Hydration properties of dietary fibre and resistant starch: a European collaborative study. LWT-Food Science and Technology. 33: 72-79.

Rodriguez-Garcia, M., De Lira, C., Hernandez-Becerra, E., Cornejo-Villegas, M., Palacios-Fonseca, A., Rojas-Molina, I., Reynoso, R., Quintero, L., Del-Real, A. and Zepeda, T. 2007. Physicochemical characterization of nopal pads (Opuntia ficus indica) and dry vacuum nopal powders as a function of the maturation. Plant Foods for Human Nutrition. 62: 107-112.

Saenz, C. 2000. Processing technologies: an alternative for cactus pear (Opuntia spp.) fruits and cladodes. Journal of Arid Environments. 46: 209-225.

Saenz, C. 2006. Opuntia spp. Bioactive compounds in foods: a plus for health. International Society for Horticultural Science (ISHS), Leuven, Belgium, 231-240.

Saenz, C. and Berger, H. 2006. Utilización agroindustrial del nopal, Food \& Agriculture Org.

Saenz, C., Sepúlveda, E., Pak, N. and Lecaros, M. 2010. Chemical and physical characterization of cactus cladode (Opuntia ficus-indica) powder. Italian Journal of Food Science. 22: 416.

Sanchez-Tapia, M., Aguilar-López, M., Pérez-Cruz, C., PichardoOntiveros, E., Wang, M., Donovan, S. M., Tovar, A. R. and Torres, N. 2017. Nopal (Opuntia ficus indica) protects from metabolic endotoxemia by modifying gut microbiota in obese rats fed high fat/sucrose diet. Scientific reports. 7: 1-16.

Scheinvar, L. 2004. Flora cactológica del estado de Querétaro: diversidad y riqueza.

Stintzing, F. C. and Carle, R. 2005. Cactus stems (Opuntia spp.): A review on their chemistry, technology, and uses. Molecular nutrition \& food research. 49: 175-194.

Ventura-Aguilar, R. I., Bosquez-Molina, E., Bautista-Baños, S. and Rivera-Cabrera, F. 2017. Cactus stem (Opuntia ficus-indica Mill): anatomy, physiology and chemical composition with emphasis on its biofunctional properties. Journal of the Science of Food and Agriculture. 97: 5065-5073.

Weickert, M. O. and Pfeiffer, A. F. 2018. Impact of dietary fiber consumption on insulin resistance and the prevention of type 2 diabetes. The Journal of nutrition. 148: 7-12.

Young, J. E., Zhao, X., Carey, E. E., Welti, R., Yang, S. S. and Wang, W. 2005. Phytochemical phenolics in organically grown vegetables. Molecular Nutrition \& Food Research. 49: 11361142. 